\title{
AN IMMUNOFLUORESCENCE STUDY OF RHEUMATOID FACTOR*
}

\author{
BY \\ J. N. MCCORMICK \\ Oxford Regional Rheumatic Diseases Research Centre, Stoke Mandeville Hospital, Aylesbury, Bucks.
}

The rheumatoid factor group of macroglobulins is a characteristic concomitant of rheumatoid arthritis and can be detected readily in the serum of most rheumatoid patients by a variety of serological techniques employing as reactant either human gamma globulin (Heller, Jacobson, Kolodny, and Kammerer, 1954; Singer and Plotz, 1956; Epstein, Johnson, and Ragan, 1956) or erythrocytes sensitized with rabbit antibody (Waaler, 1940; Rose, Ragan, Pearce, and Lipman, 1948). Various workers applying the immunofluorescence technique of Coons and Kaplan (1950) have studied the distribution of rheumatoid factor in the tissues of rheumatoid patients (Kaplan and Vaughan, 1959; Mellors, Heimer, Corcos, and Korngold, 1959; Kaplan, Suchy, and Meyeserian, 1960; Mellors, Nowoslawski, Korngold, and Sengson, 1961b; Mellors, Nowoslawski, and Korngold, 1961a). Employing aggregated human gamma globulin and rabbit immune complexes labelled with fluorescent tracers and known to react with rheumatoid factor in serological studies (Edelman, Kunkel, and Franklin, 1958; Christian, 1958), Mellors and his associates located rheumatoid factor reactive with both types of reagent in plasma cells in synovium and lymph nodes as well as in the intrinsic cells of germinal centres in lymphoid follicles. From the results of their mixed staining experiments with contrastingly labelled reagents (1961b), they concluded that there were at least two types of cellular rheumatoid factor which occur separately or simultaneously in individual plasma cells, but that only one or the other was present in germinal centres. Kaplan and his colleagues reported that rabbit gamma globulin as well as aggregated human gamma globulin reacted with plasma cells and germinal centre cells in rheumatoid lymph nodes (Kaplan and others, 1960) and that rabbit gamma

* Based on a paper read at a meeting of the Heberden Society on September 28, 1962. globulin apparently located rheumatoid factor at sites in perivascular collagenous connective tissue in rheumatoid synovium (Kaplan and Vaughan, 1959). More recently, Hess and Ziff (1961) have used fluorescent aggregated human gamma globulin to detect rheumatoid factor on leucocytes and platelets from patients with juvenile and adult rheumatoid arthritis.

The present investigation has been concerned mainly with the distribution of rheumatoid factor in lymph nodes and synovium and, although similar techniques were employed, the results obtained are not entirely in agreement with those of Mellors and his colleagues. In addition, further observations have been made which may allow the elaboration of an hypothesis concerning the nature and biological function of rheumatoid factor.

\section{Methods and Materials}

\section{Preparation of Conjugates}

In earlier experiments, the protein reagents were conjugated with fluorescein isocyanate by the method of Coons and Kaplan (1950), but at a later stage, conjugation with fluorescein isothiocyanate, as described by Riggs, Seiwald, Burckhalter, Downs, and Metcalf (1958), was used routinely. Conjugation with lissamine rhodamine B 200 was carried out by modification of the technique of Chadwick, McEntegart, and Nairn (1958). In each case, a protein concentration of $10 \mathrm{mg} . / \mathrm{ml}$. was employed. Free dye was removed by absorption on a column of Dowex ion-exchange resin $(1 \times 10,200-400$ mesh) equilibrated in $0.01 \mathrm{M}$ phosphate buffered isotonic saline $(\mathrm{pH}-7 \cdot 2)$ followed by dialysis against the same buffer for 24 hours. All conjugates were absorbed twice with acetone-dried guinea-pig liver powder and three times with washed human AB cells, and in addition all except the anti-human globulin conjugates were absorbed with lyophilized whole human spleen.

\section{Fluorescent Aggregated Human Gamma Globulin}

The human gamma globulin (HGG) used routinely was obtained from a pool prepared by the method of 
Kekwick and Mackay (1954). A small quantity of human Cohn fraction II was available for comparison with this preparation and was found to give similar results. The absorbed conjugates were heated in a water bath at $63^{\circ} \mathrm{C}$. for 5-10 minutes to aggregate the HGG and were centrifuged in the cold for 30 minutes at 16,000 r.p.m. before use. Sodium sulphate precipitation as used by Mellors and others (1959) was not employed routinely as the redissolved precipitates tended to be unstable. Similarly, the aggregates were unstable if the protein concentration exceeded $10 \mathrm{mg} . / \mathrm{ml}$. or if the heating was prolonged. The reactivity of the heated $\mathrm{HGG}$ conjugates with rheumatoid factor was assessed by their ability in high dilution (e.g. 1/1,000) to inhibit the agglutination of sensitized sheep cells by two agglutinating doses of a standard rheumatoid serum. Heat aggregation of the labelled HGG was not essential for the subsequent staining reactions, however, as even the unheated conjugates produced convincing although less intense staining. Presumably this was due to some denaturation of the HGG during conjugation and dialysis, etc.

\section{Fluorescent Rabbit Globulin Reagents}

In preliminary experiments where the distribution of globulin in rheumatoid tissues was being studied, fluorescent rabbit anti-human globulin antiserum exhaustively absorbed with normal human serum was used as a control of specificity. Although this absorbed conjugate did not react with normal human tissues, it was found that some staining persisted in rheumatoid tissues. When rheumatoid serum was used to absorb the antiserum, the residual staining was reduced but not abolished. It was thought that traces of soluble antigen-antibody complexes in the absorbed antiserum might be responsible for the reaction with rheumatoid tissues but, as fluorescent normal rabbit globulin produced similar staining, it appeared that aggregation of the rabbit globulin in an immune complex was not essential for this reaction.

In order to compare our findings with those of Mellors and others (1961a), however, soluble complexes of rabbit anti-bovine albumin and labelled bovine albumin (BSA) were prepared according to their technique. In all, four types of rabbit globulin reagent were used:

(1) Labelled rabbit anti-human globulin antiserum absorbed with normal human serum;

(2) Labelled pooled normal rabbit globulin;

(3) Rabbit anti-BSA/labelled BSA complexes;

(4) Labelled rabbit anti-BSA globulin, absorbed with normal human serum to remove crossreacting antibodies (presumably traces of soluble antigen-antibody complexes may have been present).

The staining reactions described subsequently for the rabbit globulin reagents apply equally to all four.

\section{Fluorescent Anti-human Globulin Antisera}

(1) A potent anti-human globulin antiserum pool was obtained from rabbits immunized with alum-precipitated human globulin.

(2) An anti-human gamma globulin (7S) antiserum was raised in rabbits against a pure preparation of $7 \mathrm{~S}$ gamma globulin obtained by fractionation on DEAE cellulose. Immunoelectrophoresis showed no evidence of other antibodies.

(3) An anti-19S gamma globulin antiserum was obtained from a rabbit injected with cryoglobulin from a patient with macroglobulinaemia and was absorbed with pure $7 \mathrm{~S}$ gamma globulin and the serum of a patient with hypogammaglobulinaemia. This antiserum gave a reaction of identity with an antiserum raised against normal 19S gamma globulin and was regarded as specific for this class of globulin.

The labelled anti-human globulin antiserum (1) was used routinely for general assessment of the globulin content of tissues, while the more immunospecific anti-7S and anti-19S gamma globulin antisera were reserved for detailed examination of selected tissues.

\section{Tissues Examined}

(1) Rheumatoid Biopsy Material.-Fourteen lymph nodes ( 3 epitrochlear, 10 axillary, 1 cervical) from nine patients with sero-positive rheumatoid arthritis; three subcutaneous nodules; two specimens of muscle; eighteen specimens of synovium obtained at arthrotomy from sixteen rheumatoid patients, one of whom was seronegative although the diagnosis of rheumatoid arthritis was unequivocal.

(2) Rheumatoid Post-mortem Material-41 lymph nodes obtained from two subjects with sero-positive arthritis.

(3) Control Material.-Eighteen assorted lymph nodes from five normal subjects, two mesenteric nodes from a case of rheumatic carditis, and two hilar nodes from two subjects with bronchial carcinoma were obtained at autopsy; ten specimens of normal synovium from ten meniscectomies; two specimens from osteo-arthritic knees and one from the knee of a patient with psoriatic arthritis were obtained at exploratory arthrotomy.

Small blocks of tissue were quick-frozen at $-70 \mathrm{C}$. in a mixture of dry ice and acetone. The specimens of synovium were suspended in 5 per cent. buffered gelatin during freezing, which facilitated subsequent sectioning of the blocks. All blocks were stored in the deep-freeze at -20 C. until required. In addition, portions of each biopsy specimen and a selection of the autopsy material were fixed in formalin and embedded in paraffin for routine histological staining with haematoxylin and eosin and with methyl green-pyronin. Where indicated, sections from the frozen blocks were also stained by routine histological procedures for comparison with adjacent fluorescent sections. The biopsied lymph nodes were generally hyperplastic and showed wellmarked follicle formation with prominent germinal 
centres, sinus hyperplasia, and numerous plasma cells. The rheumatoid nodes obtained at autopsy showed changes ranging from atrophy to moderate hyperplasia and were comparable to the control material. The rheumatoid synovial specimens exhibited various degrees of rheumatoid synovitis.

\section{Fluorescence Staining and Inhibition Procedures}

As required, sections approximately $4 \mu$ in thickness were cut from the frozen tissue blocks in a cryostat at $-18^{\circ} \mathrm{C}$. and allowed to dry on slides at room temperature. Fixation was not employed routinely.

(1) Single Staining Procedures.-In most cases the sections were exposed to one or two drops of the appropriate conjugate for 1 hour at room temperature, washed in three changes of buffered saline, and then mounted in buffered glycerol ( 90 per cent.).

(2) Mixed-Staining Procedures.-In direct mixedstaining procedures, the sections were exposed to a mixture of equal volumes of two contrastingly labelled reagents for 1 hour. In sequential mixed-staining procedures, where the contrastingly labelled reagents were applied consecutively, one was allowed to react with the sections for 18 hours before the second reagent was applied for 30 to 60 minutes, while on adjacent sections the sequence was reversed. Usually the sections were washed and examined under the microscope before the second conjugate was applied.

In parallel experiments the direct and sequential mixed staining procedures were repeated with the fluorescent labels reversed. This step was included to ensure that the reactivity of each globulin preparation was not influenced by the particular method of conjugation employed.

(3) Direct Inhibition Procedures.-One drop of conjugate was mixed on the sections with one drop of the corresponding unlabelled protein solution which had been applied 18 hours previously, and staining was allowed to proceed for 15 to 30 minutes. Under these conditions complete or substantial inhibition was obtained, and the staining observed on control sections where buffered saline was substituted for the unlabelled protein was accepted as specific. By these criteria the fluorescence staining reactions reported in this study were specific.

(4) Cross-Inhibition Procedures.-In conjunction with the direct and sequential mixed staining procedures, each of the conjugates under study was replaced in turn by the corresponding unlabelled protein and applied to the section 18 hours before, or as a mixture with, the other conjugate. In each case the sections were exposed to the conjugate for 30 minutes and compared with control sections on which buffered saline replaced the unlabelled protein.

\section{Fluorescence Microscopy}

The fluorescence microscope used in this department has been described previously by Scott (1960).

\section{Results}

Fluorescent Aggregated Human Gamma Globulin. - In sections of rheumatoid lymph nodes stained with the fluorescent aggregate, bright specific fluorescence was seen mainly in scattered cells lying in the medullary cords, commonly in a perifollicular distribution, and sometimes in the sinuses. These cells were in all respects similar to those described in detail and illustrated by Mellors and others (1959). Many of these appeared to be various types of plasma cell, Russell body cells being the most striking and relatively numerous in some sections. In most sections there were also ring type cells with a narrow rim of fluorescent cytoplasm and a central unstained nucleus, resembling small and large lymphocytes. These may be immature plasma cells, as suggested by the previous workers, or similar to the "lymphocytoid plasma cells" found in Waldenström's macroglobulinaemia (Dutcher and Fahey, 1959).

In the more hyperplastic lymph nodes, but rarely in others, bright specific fluorescence was seen in germinal centres. On the whole, comparatively few germinal centres reacted with the fluorescent aggregate, although abundant macroglobulin could be demonstrated in the majority of germinal centres when sections previously exposed to the fluorescent aggregate were counterstained with the specific anti-19S antiserum labelled contrastingly. Rheumatoid factor reactivity in germinal centres was located in the cytoplasm of the large intrinsic cells and in many sections the fluorescence was most intense in the cells in the central portion of the germinal centre, tending to tail off peripherally in a fine cytoplasmic or pericytoplasmic reticulum which ended abruptly at the collar of mature lymphocytes. Rheumatoid factor was not found in the peripheral rim of lymphocytes except in an occasional cell identified as a plasma cell. In some instances, plasma cells including Russell body types exhibiting rheumatoid factor activity were located in germinal centres where the intrinsic cells themselves were devoid of rheumatoid factor. Although in some sections where this was observed the plasma cells may have been imprints on the germinal centre, in others counterstained with contrastingly labelled anti-human globulin antiserum the plasma cells appeared to be an integral part of the reactive follicle. 


\section{ANNALS OF THE RHEUMATIC DISEASES}

In sections of rheumatoid synovium examined, germinal centres were invariably absent, and rheumatoid factor activity was found mainly in mature and immature plasma cell types lying in the subsynovial connective tissue, occasionally in a perivascular distribution. In the tissues showing the most florid rheumatoid synovitis, with well-marked follicle formation, large cellular aggregates of rheumatoid factor were sometimes seen. As might be expected, in sections showing more chronic rheumatoid changes with less inflammatory cell infiltration cellular rheumatoid factor was often very scanty, and in all instances cells showing rheumatoid factor reactivity constituted only a small proportion of the total number of plasma cells present. Even so, in the one case of seronegative rheumatoid arthritis examined, a few faintly staining plasma cells were found in the subsynovial connective tissue. In addition to staining of plasma cell types, dull but specific fluorescence was seen in the cytoplasm of the synovial cells in several specimens, and this reactive material could not be removed by prior washing of the sections or by irrigation of the tissue with buffered saline before quick-freezing. It is not clear whether this was a diffusion artifact or perhaps represented material containing rheumatoid factor globulin and absorbed by the phagocytic action of the synovial cells.

Only limited information is available from the examination of the chronic subcutaneous nodules. On one occasion rheumatoid factor was detected in a few plasma cells in the peripheral zone of a nodule but in most sections dull specific fluorescence was seen in the amorphous fibrinoid material in the central region. In all other tissues examined, rheumatoid factor detectable by the fluorescent aggregate was entirely intracellular apart from faint traces in the lumen of blood vessels, and globules and amorphous aggregates which may have been extruded by plasma cells or resulted from cell disintegration. Such extracellular deposits were haphazard in distribution and did not appear to be related specifically to any connective tissue element.

Fluorescent Rabbit Globulin Reagents.-When the same tissues were studied with the various rabbit globulin reagents, with some reservations, a similar distribution of rheumatoid factor reactivity was encountered. Rheumatoid factor was found in similar plasma cell types, but these were usually fewer in number than detected by the fluorescent aggregate in adjacent sections. On the other hand, more germinal centres were stained by the rabbit globulins than by the fluorescent aggregate. In some sections the number of germinal centres stained was comparable to the number seen in adjacent sections exposed to the labelled anti-19S antiserum.

In addition to the two categories of cellular rheumatoid factor, rheumatoid factor reactivity was detected by the rabbit globulin reagents at various extracellular sites-the lumen, media, and adventitia of blood vessels, lining the walls of sinuses, and as streaks applied to connective tissue and among bundles of collagen. On the whole these extracellular reactions were rather faint and less striking than cellular staining, but they parallelled to some extent the extracellular distribution of macroglobulin.

Inhibition Procedures.-In cross-inhibition procedures, staining by the fluorescent aggregate was usually inhibited to some extent, but never completely by the rabbit anti-BSA globulin, the immune

Dark-ground illumination and a water immersion objective were employed routinely for colour photography. All fluorescence photomicrographs were taken on Super Anscochrome daylight type $35-\mathrm{mm}$. film. Exposure times ranged from $2 \frac{1}{2}-10 \mathrm{minutes}$.

Fig. 1.-Rheumatoid synovium. Collection of immature plasma cells stained by fluorescein-labelled aggregate $(\times 160)$.

Fig. 2.-Germinal centre in rheumatoid lymph node. Fluoresceinlabelled aggregate followed by rhodamine-labelled anti-human globulin antiserum. The intrinsic cells have not reacted with the labelled aggregate. The yellow-green plasma cells (including Russell body types) contain rheumatoid factor ( $\times 160)$.

Fig. 3.-Germinal centre in rheumatoid lymph node. Rhodaminelabelled aggregate followed by fluorescein-labelled anti-19S antiserum.

Yellow cells have reacted with both reagents. Mainly green fluorescence towards the periphery. $(\times 160$.)

Fig. 4.-Central region of large ovoid germinal centre in rheumatoid lymph node stained by rhodamine-labelled aggregate $(\times 160)$.

Fig. 5.-Same germinal centre as in Fig. 4. Rhodamine-labelled aggregate followed by rabbit anti-BSA/fluorescein-labelled BSA complex. Central region of germinal centre at right. Transition from orange-red to yellow-orange, yellow, yellow-green, and green from centre towards periphery. $(\times 160$.
Fig. 6.-Germinal centre in rheumatoid lymph node. Rhodaminelabelled aggregate followed by fluorescein-labelled rabbit anti-BSA Orange-red, green, and traces of yellow fluorescence shown. Green mainly at periphery. $(\times 160$.

Fig. 7.-Germinal centre in rheumatoid lymph node. Fluoresceinlabelled anti-19S antiserum followed by rhodamine-labelled anti-7S antiserum. Yellow mixture of fluorescence at periphery and mainly green towards the central region. $(x 160$.

Fig. 8.-Periphery of germinal centre in rheumatoid lymph node. Fluorescein-labelled anti-19S antiserum preceded rhodamine-labelled anti-7S antiserum. Green and yellow mixed fluorescence shown together in individual intrinsic cells. ( $\times 240$.)

Fig. 9.-Rheumatoid lymph node. Fluorescein-labelled anti-19S antiserum followed by rhodamine-labelled anti-7S antiserum.

Unusually large plasma cell shows yellow fluorescence in cytoplasm with traces of orange-red at periphery. The cell membrane has apparently ruptured above, releasing a shower of yellow and orange globules. Two larger Russell bodies on the right show yellow fluorescence. Cytoplasm of smaller plasma cell is mainly green, apart from yellow specks at upper pole and yellow rim around nucleus. $(\times 400$.) 
IMMUNOFLUORESCENCE STUDY OF RHEUMATOID FACTOR

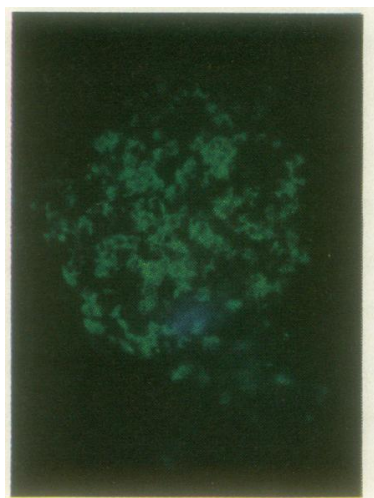

I

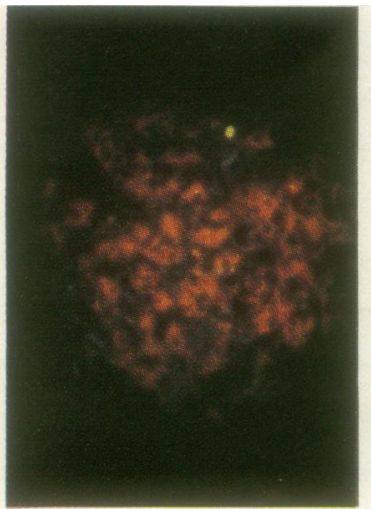

4

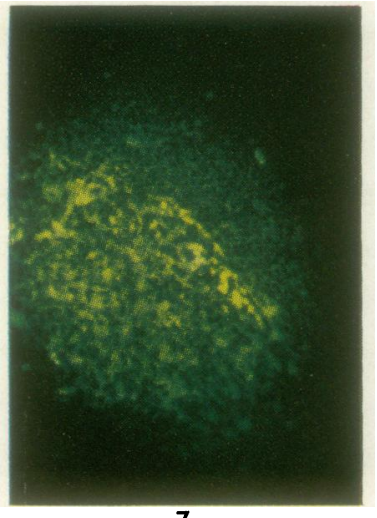

7

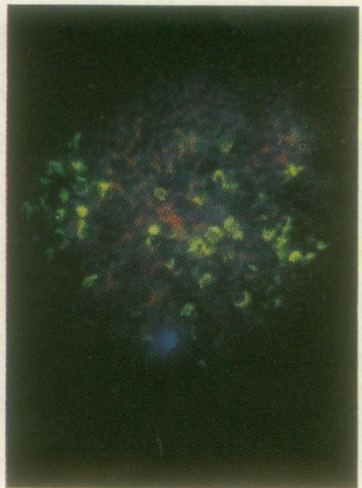

2

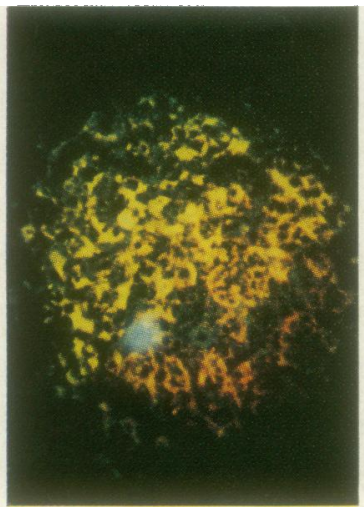

5

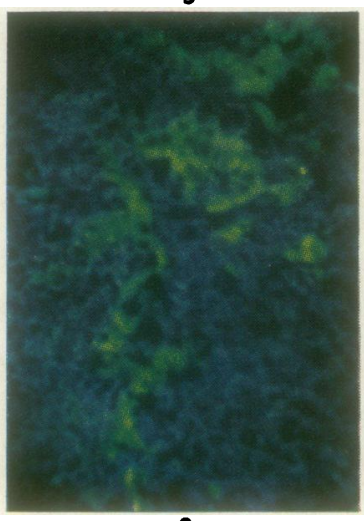

8

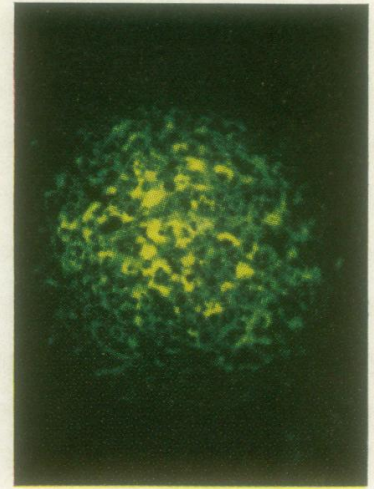

3

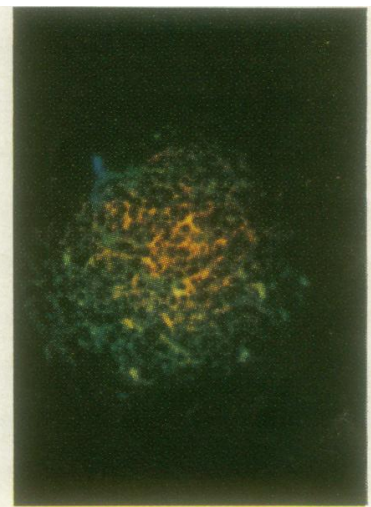

6

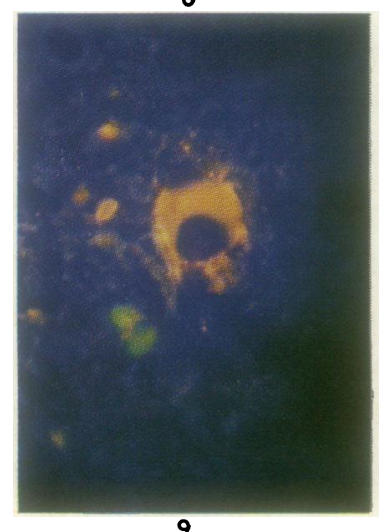

Facing p. 4] 
complex, absorbed rabbit anti-human globulin antiserum, normal rabbit globulin, and a variety of immune rabbit globulins, including anti-human glomerulus, anti-human A cells, anti-sheep cells, anti-ox cells, and anti-dextran (Leuconostoc mesenteroides). It was not possible to produce convincing inhibition by pre-treatment of sections with the rabbit anti-19S antiserum because the brief application of the fluorescent aggregate apparently completed a fluorescent sandwich which reproduced the pattern of staining seen in adjacent sections treated directly with the labelled anti-19S antiserum. This difficulty was encountered with labelled aggregated Cohn fraction II as well as with the aggregate used routinely and, as the anti-19S antiserum had been absorbed free of cross-reactivity with $7 \mathrm{~S}$ gamma globulin, the staining was presumably due to a small content of labelled macroglobulin in the gamma globulin preparations. It should be noted, however, that when the anti-19S antiserum was omitted, staining produced by the fluorescent aggregate was more intense, although limited in distribution, and it seems likely that the anti-19S antiserum produced relative inhibition despite the sandwich effect. In view of this difficulty and the fact that "non-specific" rabbit globulins inhibited staining, any inhibition produced by the specific anti-19S antiserum could not be interpreted directly as demonstrating the macroglobulin nature of the cellular proteins reacting with the fluorescent aggregate.

Staining by the fluorescent rabbit globulins was usually inhibited by pre-treatment of the sections with unlabelled aggregated human gamma globulin, but the degree of inhibition was variable and, although often virtually complete, extracellular staining was not inhibited and in some sections plasma cells and germinal centres were still brightly stained. On the other hand, complete inhibition was produced by a variety of normal and immune rabbit globulins so that again inhibition by the anti-19S antiserum was not conclusive evidence that the reactive tissue proteins were macroglobulins.

Mixed-Staining Procedures.-When the rhodamine-labelled aggregate and one or other of the fluorescein-labelled rabbit globulin reagents were applied as a mixture or in sequence, three types of rheumatoid factor activity could be distinguished according to the colours of the resulting fluorescence (Table).

These results were not influenced by reversing the sequence in which the conjugates were applied or by interchanging the fluorescent labels. In lymph
TABLE

COLOUR OF FLUORESCENCE RELATED TO TYPE OF RHEUMATOID FACTOR ACTIVITY

\begin{tabular}{c|c|c}
\hline $\begin{array}{c}\text { Rheuma- } \\
\text { toid } \\
\text { Factor }\end{array}$ & Fluorescence & Specificity \\
\hline TYPE I & Orange-red & $\begin{array}{c}\text { Reaction with aggregated } \\
\text { HGG only }\end{array}$ \\
\hline TYPE II & $\begin{array}{l}\text { Mixture varying from } \\
\text { yellow-green, through } \\
\text { yellow to yellow- } \\
\text { orange }\end{array}$ & $\begin{array}{c}\text { Reaction with aggregated } \\
\text { HGG and rabbit globu- } \\
\text { lin (RGG) }\end{array}$ \\
\cline { 2 - 3 } TYPE III & $\begin{array}{l}\text { Green } \\
\text { Treaction with rabbit }\end{array}$ & $\begin{array}{c}\text { Rean } \\
\text { globulin only (RGG) }\end{array}$ \\
\hline
\end{tabular}

nodes and synovium, all three types of reactivity were seen in plasma cells. The Type I (HGG) reaction was most common, but the Type II (mixed) reactions were found in moderate numbers of plasma cells, while Type III (RGG) reactivity was found in relatively few cells. In germinal centres Type $I$ staining was occasionally seen alone, but it was more common to find Type I with various combinations of the other two. Type III reactivity was seen in many germinal centres in the absence of either Type I or II and was also found exclusively at extracellular connective tissue sites. On several occasions, in germinal centres where all three types of staining reaction were present, zoning of fluorescence was observed-Type I being present in the central portion of the germinal centre and Type II in the intermediate zone with gradual transition to Type III at the periphery. Similarly, various combinations of all three types were seen in individual germinal centre cells as well as in plasma cells where even Russell bodies in the same cell occasionally showed contrasting staining reactions.

In parallel mixed-staining experiments, where the labelled rabbit globulin reagents were followed by the contrastingly labelled anti-19S antiserum, plasma cells and germinal centre cells previously stained by the non-specific rabbit globulins showed mixed fluorescence, indicating the macroglobulin nature of the Type III and presumably Type II factor. Similarly, when the labelled anti-19S antiserum followed contrastingly labelled aggregate, plasma cells and germinal centre cells previously stained by the aggregate now showed mixed fluorescence. This cannot be interpreted directly as demonstrating the macroglobulin character of the factor reacting with the aggregate, as the mixed staining might be due to a Type II reaction with HGG and "non-specific" RGG in the rabbit antiserum. It may be significant, however, that it was commonly the central portion of the germinal centre which reacted with the aggregate, the peripheral zone being 
stained only by the anti-19S antiserum, while the reverse was sometimes true when a labelled rabbit globulin reagent preceded the contrastingly labelled anti-19S antiserum. Although the macroglobulin nature of the Type I factor could not be confirmed by the techniques employed in this investigation, this can perhaps be assumed from the known distribution of macroglobulin in the tissues studied.

Distribution of 7S and 19S Gamma Globulins.As fairly limited supplies of the immunospecific anti-19S and anti-7S antisera were available, only the most hyperplastic lymph nodes and florid examples of rheumatoid synovitis were examined and compared with an appropriate selection of control tissues. The labelled anti-7S antiserum produced a wide distribution of staining in the majority of rheumatoid sections where high concentrations of globulin were found in most germinal centres and many plasma cells, while traces were seen in the sinuses, walls, and lumen of vessels, and at most connective tissue sites. The labelled anti$19 \mathrm{~S}$ antiserum produced a similar distribution of extracellular staining, but on the whole fewer plasma cells were stained. Most, if not all, of the germinal centres present in many sections reacted with this antiserum. The distribution of $7 \mathrm{~S}$ gamma globulin alone was determined by staining sections with fluorescent anti-7S antiserum after prior treatment with unlabelled anti-19S to block the cross-reaction of the anti-7S antiserum with macroglobulin. There was very little overall difference in the distribution of staining produced by this technique compared with the direct staining procedure and approximately the same number of germinal centres and plasma cells were stained. It was significant, in view of subsequent findings, that there was apparent inhibition of staining in the central portion of some germinal centres. In sequential mixed-staining procedures where sections of lymph nodes and synovium were pre-treated with fluorescein labelled anti-19S antiserum followed by rhodamine labelled anti-7S antiserum, the resulting fluorescence reactions were green in some germinal centres and plasma cells and orange-red in others, but many showed a mixture of the two colours. Extracellular fluorescence was generally of the mixed variety. In some germinal centres, zoning of contrasting fluorescence was again seen, with bright yellow and traces of orange-red at the periphery and gradual transition through yellow-green in the intermediate zone to green in the central region. Similarly, various combinations of green, orange-red, and mixed fluorescence were seen in individual germinal centre cells and plasma cells. The cells illustrated in Fig. 9 were originally stained uniformly green by the fluorescein labelled anti-19S antiserum but, when identified again after exposure to the rhodamine labelled anti-7S antiserum, it was found that orange-red and various mixed hues had been added to the original fluorescence. In comparison, when the sequence was reversed, no green fluorescence was observed and cells or parts of cells were stained either yellow or orange-red.

From these findings it appeared that, in many plasma and germinal centre cells, 7S gamma globulin was present in association or in combination with macroglobulin, although in some instances it appeared that the two classes of protein were segregated in the cytoplasm in different parts of the same cell. It seems unlikely that the mixed staining was due to a cross-reaction between the anti-7S antiserum and the previously stained macroglobulin, because in these circumstances there would have been no green cells at all, and it is perhaps reasonable to suppose that bound anti-19S antibody blocked any subsequent cross-reaction. Another possible explanation of this phenomenon is that, in cells containing rheumatoid factor macroglobulin reactive with RGG and previously stained by the fluorescein labelled anti-19S antiserum, the appearance of contrasting or mixed fluorescence after exposure to the rhodanine labelled anti-7S antiserum might be due to a reaction between rheumatoid factor and the contrastingly labelled "non-specific" rabbit globulin component in the anti-7S antiserum. Against this explanation is the observation that prior treatment of the sections with unlabelled anti-19S antiserum completely inhibited staining by the routine rabbit globulin reagents. Assuming that the antigenic and antibody sites on the rheumatoid factor molecule are separate and there is no steric hindrance, the specific antibody and the "non-specific" rabbit globulin components of the anti-19S antiserum may both be involved in this inhibition. It seems likely, therefore, that the mixed fluorescence observed with contrastingly labelled anti-19S and anti-7S antisera indicates the coexistence of macroglobulin and $7 \mathrm{~S}$ gamma globulin in germinal centre cells and plasma cells as well as at various extracellular connective tissue sites.

Control Materials.-With one exception, the lymph nodes from the controls showed no specific reaction with the fluorescent aggregate or rabbit globulin reagents. In three nodes from one normal subject, plasma cell types and reticulo-endothelial cells lining the sinuses reacted specifically with these reagents, although there was no macroscopic evidence of rheumatoid arthritis and no previous 
history of rheumatic symptoms. No serology was available, but in most subsequent cases sensitized sheep cell and latex-fixation tests were performed on fresh or post mortem serum, all of which were negative. In one specimen of osteo-arthritic synovium (sero-negative) a reaction was obtained between fibroblasts and the fluorescent aggregate, but no plasma cells were seen. The remainder of the tissues gave no reaction with the rheumatoid factor reagents. Globulin, especially macroglobulin, was scanty in most control tissues and germinal centres rarely contained more than a trace if any at all. One of the two specimens of osteo-arthritic synovium and the one psoriatic synovium showed moderate amounts of globulin bound at connective tissue sites, but this lacked rheumatoid factor activity.

\section{Discussion}

On the basis of results obtained from the crossinhibitions and mixed staining procedures with contrastingly labelled aggregated human gamma globulin and the rabbit globulin reagents, it has been established that many plasma cells and fewer germinal centre cells reacted with HGG alone (Type I), more germinal centre cells and fewer plasma cells reacted with RGG alone (Type III), and moderate numbers of each reacted with both HGG and RGG (Type II). In addition, the Type III reaction occurred at scattered connective tissue sites.

Mellors and others (1961b) suggested that the three types of fluorescence found in their mixedstaining experiments indicated that some plasma cells formed a rheumatoid factor detected only with fluorescent aggregate, some formed a second demonstrable with fluorescent immune complex as well as with fluorescent aggregate, and still others formed both. Earlier (1961a), these authors had suggested that there might be several (two or more) factors directed against different antigenic components of aggregated human gamma globulin and that some of these components were present in the rabbit immune complex. From the results of the present investigation, however, where cells showing green fluorescence were found in sections exposed to the fluorescein labelled rabbit globulin reagents following pre-treatment with rhodamine labelled aggregate, it appears that there must also be a factor which reacts only with rabbit (heterologous) gamma globulin. Furthermore, it is likely that the mixed fluorescence observed in these circumstances must be due either to the simultaneous presence of at least two factors with individual specificity for HGG or RGG or to a single factor capable of reacting with separate components in HGG and RGG. It would be difficult to explain this phenomenon otherwise, and it does not seem logical to suggest that mixed staining is due to a factor which reacts primarily with HGG and cross-reacts with RGG, as it would be expected that such cross-reactions would be blocked by prior exposure of the sections to the labelled aggregate.

The mixed-staining experiments which suggested that $7 \mathrm{~S}$ globulin might be associated in varying degrees with macroglobulin in germinal centre cells and plasma cells might provide an alternative explanation of the three types of rheumatoid factor reactivity observed at similar sites. If the zoning of contrasting fluorescence which was seen in some germinal centres in mixed staining with the anti-19S and anti-7S antisera can be correlated with the similar zoning of staining with the contrastingly labelled aggregate and rabbit globulin reagents, it would seem that, as the concentration of $7 \mathrm{~S}$ gamma globulin decreased from the periphery inwards, so the reactivity of rheumatoid factor with the fluorescent aggregate decreased from the centre outwards. This might suggest that the Type I reaction was progressively inhibited as the concentration of cellular $7 \mathrm{~S}$ gamma globulin increased, while there was gradual transition through Type II reactivity in the intermediate zone to Type III at the periphery in direct proportion to the concentration of 7S gamma globulin. Similarly, this might apply to different sites in individual plasma cells. If this assumption is valid and the varying reactivity of cellular rheumatoid factor depends upon the ratio within the cell of $7 \mathrm{~S}$ gamma globulin to a "stem" 19 S rheumatoid factor whose inherent specificity is directed entirely against HGG, the combination of the $7 \mathrm{~S}$ gamma globulin with the reactive sites on the $19 \mathrm{~S}$ nucleus may confer upon the rheumatoid factor additional affinity for rabbit (heterologous) gamma globulin. This might occur if such 7S gamma globulin itself possessed an inherent affinity for heterologous gamma globulin and at the same time blocked sites on the rheumatoid factor nucleus reactive with further HGG. Alternatively, the reaction of the $7 \mathrm{~S}$ gamma globulin with the 19S nucleus might alter the configuration of either component so that sites reactive with heterologous gamma globulin were exposed. Najjar and Robinson (1959) have indicated that antigenantibody complexes may have antigenic determinants not originally present in either component, and it is conceivable that rheumatoid factor reactivity with heterologous gamma globulin may be acquired in a similar fashion. If this were so, depending on the degree of aggregation with cellular $7 \mathrm{~S}$ gamma globulin, the resulting partially-saturated complexes might react with toth HGG and hetero- 
logous gamma globulin, while further saturation might produce a factor reactive with only heterologous globulin. In cells where "stem" $19 S$ rheumatoid factor was present in the absence of $7 \mathrm{~S}$ gamma globulin, $r$ - ctivity only with HGG may be encountered. Thus rheumatoid factor molecules could be produced with various sedimentation coefficients depending on the degree of aggregation and with corresponding transition of reactivity. It is well known that high molecular weight complexes occur in rheumatoid sera, possibly with different molar ratios of 7 and 19S gamma globulin (Franklin, Holman, Müller-Eberhard, and Kunkel, 1957), and it is conceivable that a proportion of these complexes may be formed intracellularly. An attempt such as this to equate the various types of cellular rheumatoid factor activity with the size of the molecular complexes would not necessarily be valid for the standard serological procedures where a dynamic equilibrium might exist, allowing dissociation and re-association of complexes which could not occur at cellular level in tissue sections. Further, Epstein and Tan (1961) have observed dissociation of a $22 \mathrm{~S}$ complex on anionic column chromatography and, if it were necessary for this hypothesis to account for the sensitized sheep cell agglutinating activity of $19 \mathrm{~S}$ rheumatoid factor isolated by such techniques (Lospalluto and Ziff, 1959), one might postulate that some heterospecificity had survived in partially dissociated complexes not resolved from "stem" 19 S rheumatoid factor in the ultracentrifuge.

The possibility that rheumatoid factor may be an antibody-antibody complex has been considered by Najjar and Robinson (1959); Dubiski (1958) suggested that rheumatoid factor was an anti-antibody and others indicated that it might represent an antibody to altered human gamma globulin (Glynn, Holborow, and Johnson, 1927). The presence of rheumatoid factor in plasma cells and the intrinsic cells of germinal centres suggests though it does not confirm its antibody nature and it may be possible to extend the interpretation of the results of this investigation by postulating that "stem" rheumatoid factor arises in one cell or germinal centre in response to an antigenic stimulus from an abnormal 7S gamma globulin being produced at another site which may be distant or in the same cell or germinal centre. If such abnormal gamma globulins were, for instance, autoantibody directed against connective tissue antigens, then rheumatoid factor might play a protective role by complexing with such autoantibodies as they are produced. When pre-formed complexes are eventually released from the cell, the rheumatoid factor may prevent or modify the reaction with the antigen against which the autoantibody is directed, perhaps by preventing fixation of complement. It is also implicit in this hypothesis that the reaction between rheumatoid factor and autoantibody in the parent cell could not result in damage, as such cells would not survive. Not all 7S gamma globulin present in circulating rheumatoid factor complexes need be autoantibody in view of the indication that isolated $19 \mathrm{~S}$ rheumatoid factor can complex with normal gamma globulin (Edelman, Kunkel, and Franklin, 1958). It is likely that $19 \mathrm{~S}$ rheumatoid factor liberated from Type I cells would be capable of forming equilibrium complexes with normal $7 \mathrm{~S}$ gamma globulin in the serum, and that partially saturated complexes of rheumatoid factor and autoantibody released from Type II cells may become saturated by aggregation with normal 7S gamma globulin without displacement of the autoantibody. In addition, the ratio of normal to abnormal $7 \mathrm{~S}$ in the complexes may vary according to activity of the disease and the degree of antigenic stimulation.

The results of further work around this theme (McCormick, to be published) indicate that absorption of rheumatoid factor from selected rheumatoid sera results in loss of antinuclear factor activity, which suggests that rheumatoid factor-autoantibody complexes are a possibility. Kaplan and Vaughan (1959) suggested that rheumatoid factor and reactant gamma globulin may occur bound in the tissues, possibly in the form of complexes, and, on the basis of the assumptions outlined above, it is possible that the extracellular Type III reactions noted in this study represent saturated rheumatoid factor complexes bound specifically to connective tissue antigens. As a corollary, it is likely in investigations of this kind that fluorescent aggregated human gamma globulin would not detect specifically bound rheumatoid factor.

Finally, the coexistence of $7 \mathrm{~S}$ gamma globulin and macroglobulin in individual cells may indicate merely a maturation process in which macroglobulin is being produced by the aggregation of $7 \mathrm{~S}$ molecules. Deutsch and Morton (1957), from their studies on the dissociation of macroglobulins by mercapto-ethanol treatment, suggested that macroglobulins might be formed from normal 7S sub-units. Presumably, therefore, such aggregation could occur intracellularly but, on the whole, the hypothesis, however tenuous, which allows a protective biological role for rheumatoid factor seems more attractive.

\section{Summary}

Fluorescent aggregated human gamma globulin and normal or immune rabbit globulins have been 
used to trace the distribution of rheumatoid factor in rheumatoid lymph nodes and synovium. Rheumatoid factor was detected by each class of reagent in plasma cells in lymph nodes and synovium, and in the intrinsic cells of reactive follicles. The labelled rabbit globulin reagents also reacted with rheumatoid factor at various extracellular connective tissue sites. Mixed-staining experiments with contrastingly labelled aggregated human gamma globulin and the rabbit globulins showed that some plasma cells and intrinsic cells reacted with either the aggregate or the rabbit globulins and that others reacted with both. Various combinations of each fluorescence reaction were found in individual cells and germinal centres. Mixed-staining procedures with contrastingly labelled anti-7S and a specific anti-19S antisera indicated that $7 \mathrm{~S}$ gamma globulin was associated with macroglobulin at similar sites, and it is suggested that the varying reactivity of rheumatoid factor with the aggregate and rabbit globulins depends upon the ratio of native $7 \mathrm{~S}$ gamma globulin to a "stem" $19 \mathrm{~S}$ rheumatoid factor in rheumatoid factor complexes. In addition, it was postulated that rheumatoid factor might arise as an antibody to autoantibody with which it complexes intracellularly, preventing or modifying subsequent reactions with connective tissue antigens. Finally, the possibility that macroglobulins may be formed from intracellular aggregation of $7 \mathrm{~S}$ gamma globulin was considered.

I wish to thank A.G.S. Hill and Dr. D. G. Scott for much helpful discussion and criticism.

I am grateful to Dr. J. F. Soothill, University of Birmingham, for providing the anti-7S and anti-19S gamma globulin antisera, and to Dr. W. d'A. Maycock, Lister Institute of Preventive Medicine, for supplying the human gamma globulin.

Dr. C. L. Greenbury kindly supplied the Cohn fraction II and various rabbit antisera.

The lissamine rhodamine B 200 was supplied by Imperial Chemical Industries, Dyestuffs Division.

I am indebted to the Nuffield Foundation and the Empire Rheumatism Council whose grants to the Rheumatism Research Centre enabled this work to be pursued.

\section{REFERENCES}

Chadwick, C. S., McEntegart, M. G., and Nairn, R. C. (1958). Lancet, 1, 412.

Christian, C. L. (1958). J. exp. Med., 108, 139.

Coons, A. H., and Kaplan, M. H. (1950). Ibid., 91, 1.

Deutsch, H. F., and Morton, J. I. (1957). Science, 125,600 .

Dubiski, S. (1958). Fol. biol., 6, 47.

Dutcher, T. F., and Fahey, J. L. (1959). J. nat. Cancer Inst., 22, 887.
Edelman, G. M., Kunkel, H. G., and Franklin, E. C. (1958). J. exp. Med., 108, 105.

Epstein, W., Johnson, A., and Ragan, C. (1956). Proc. Soc. exp. Biol. (N.Y.), 91, 235.

Epstein, W. E., and Tan, M. (1961). Arthr. and Rheum., 4, 414 (Abstract).

Franklin, E. C., Holman, H. R., Müller-Eberhard, H. J., and Kunkel, H. G. (1957). J. exp. Med., 105, 425.

Glynn, L. E., Holborow, E. J., and Johnson, G. D. (1957). Proc. roy. Soc. Med., 50, 469.

Heller, G., Jacobson, A. S., Kolodny, M. H., and Kammerer, W. H. (1954). J. Immunol., 72, 66.

Hess, E., and Ziff, M. (1961). Arthr. and Rheum., 4, 574.

Kaplan, M. H., Suchy, M. L., and Meyeserian, M. (1960). Ibid., 3, 272 (Abstract).

- and Vaughan, J. H. (1959). Ibid., 2, 356 (Abstract).

Kekwick, R. A., and Mackay, M. E. (1954). M.R.C. Spec. Rep. Ser. No. 286.

Lospalluto, J., and Ziff, M. (1959). J. exp. Med., $110,169$.

Mellors, R. C., Heimer, R., Corcos, J., and Korngold, L. (1959). Ibid., 110, 875.

—, Nowoslawski, A., and Korngold, L. (1961a). Amer. J. Path., 39, 533.

,$- \frac{1}{7}$, and Sengson, B. L. (1961b). J. exp. Med., 113, 475.

Najjar, V. A., and Robinson, J. P. (1959). In "Immunity and Virus Infection", ed. V. A. Najjar, p. 71. Wiley, New York.

Riggs, J. L., Seiwald, R. J., Burckhalter, J. H., Downs, C. M., and Metcalf, T. G. (1958). Amer. J. Path., 34, 1081.

Rose, H. M., Ragan, C., Pearce, E., and Lipman, M. O. (1948). Proc. Soc. exp. Biol. (N.Y.), 68, 1.

Scott, D. G. (1960). Immunology, 3, 226.

Singer, J. M., and Plotz, C. M. (1956). Amer. J. Med., 21,888 .

Waaler, E. (1940). $\quad$ Acta path. microbiol. scand., 17, 172.

Discussion.-Dr. J. T. ScotT (Hammersmith): May I ask Dr. McCormick about the correlation of these findings with the presence of rheumatoid factor in the serum? Has he found rheumatoid factor by these techniques in patients with negative Waaler-Rose tests?

DR. McCormick: Of the patients I have studied, all have had a positive Waaler-Rose test except one, who had definite rheumatoid arthritis, but negative sheep cell agglutination and latex-fixation tests. A few plasma cells containing rheumatoid factor were found in synovium from this subject.

\section{Etude immunofluorescente du facteur rhumatismal}

\section{RÉSUMÉ}

La globuline gamma humaine agglutinée et rendue fluorescente, et des globulines de lapin, normales et immunes, furent utilisées pour suivre la distribution du facteur rhumatismal dans les ganglions lymphatiques et la synovie des rhumatisants. Le facteur rhumatismal fut décélé par chaque type de réactif dans des plasmocytes, ganglions lymphatiques et dans la synovie, ainsi que dans les cellules intrinsèques des follicules actives. La globuline colorée de lapin réagit aussi avec le facteur rhumatismal à de différents endroits du tissu conjonctif 
extracellulaire. Des expériences de colorarion mixte, avec la globuline gamma agglutinée humaine colorée différemment des globulines de lapin, démontrèrent que certains plasmocytes et cellules intrinsèques réagirent soit avec la globuline humaine, soit avec les globulines de lapin, tandis que d'autres réagirent avec les deux. On trouva de différentes combinaisons de chaque réaction de fluorescence dans des cellules individuelles et des centres germinaux. En colorant différemment l'antisérum anti-S7 et l'antisérum spécifique anti-19S, on vit que la globuline gamma $7 \mathrm{~S}$ se trouvait associée à la macroglobuline à des endroits similaires, et on pense que la réactivité variable du facteur rhumatismal avec la globuline humaine et de lapin depend du rapport entre la globuline gamma 7S native et un facteur rhumatismal "tige" ("stem") 19S dans les complexes du facteur rhumatismal. De plus, on postule que le facteur rhumatismal pourrait se présenter comme un anticorps contre un autoanticorps, avec lequel il formerait des complexes intracellulaires, empêchant ou modifiant les réactions subséquentes avec les antigènes du tissu conjonctif. Finalement, on a considéré la possibilité que les macroglobulines seraient formées par l'aggrégation intracellulaire de la globuline gamma $7 \mathrm{~S}$.

\section{Estudio inmunofluorescente del factor reumatoide}

\section{SuMARIo}

La globulina gamma humana, aglutinada y fluorescente, así como globulinas de conejo, normales e inmunes, fueron empleadas para investigar la distribución del factor reumatoide en los ganglios linfáticos y la sinovia de enfermos reumatoides. El factor reumatoide fué evidenciado por cada clase de reactivo en plasmocitos, ganglios linfáticos y en la sinovia, así como en las células intrínsecas de los folículos activos. La globulina fluorescente reaccionó también con el factor reumatoide en varios sitios del tejido conectivo extracelular. Experiencias de coloración mixta, tiniendo diferentemente la globulina gamma aglutinada humana y las globulinas de conejo, demostraron que ciertos plasmocitos y células intrínsecas reaccionan sea con la globulina humana sea con las globulinas de conejo, mientras que otros reaccionan con ambas globulinas. Varias combinaciones de cada reacción de fluorescencia fueron encontradas en células individuales y en centros germinales. Con coloraciones de contraste del antisuero anti-7S y del antisuero específico anti-19S se pudo observar una asociación de la globulina gama $7 \mathrm{~S}$ con la macroglobulina en sitios similares y se sugiere que la reactividad variable del factor reumatoide con las globulinas humana y de conejo depende de la relación entre la globulina gamma $7 \mathrm{~S}$ nativa y un factor reumatoide "tallo" ("stem") $19 \mathrm{~S}$ en los complejos del factor reumatoide. Además, se postula que el factor reumatoide pudiera presentarse como un anticuerpo contra un autoanticuerpo y formar con él complejos intracelulares e impedir o modificar reacciones subsiguientes con antígenos del tejido conectivo. Por fin, se considera posible que las macroglobulinas sean formadas por una agregación intracelular de la globulina gamma $7 \mathrm{~S}$. 